九州大学学術情報リポジトリ

Kyushu University Institutional Repository

\title{
Application of the Direct Colony TLC Method for Identification of Phytopathogenic Bacteria
}

Matsuyama, Nobuaki

Laboratory of Plant Pathology, Faculty of Agriculture, Kyushu University

Mian, Ismail Hossain

Department of Plant Pathology, Institute of Post-graduate Studies in Agriculture (IPSA)

Akanda, Abdul Mannan

Department of Plant Pathology, Institute of Post-graduate Studies in Agriculture (IPSA)

Furuya, Naruto

Laboratory of Plant Pathology, Faculty of Agriculture, Kyushu University

https://doi.org/10.5109/24020

出版情報：九州大学大学院農学研究院紀要. 37 (3/4)，pp.283-287，1993-03. Kyushu University バージョン：

権利関係 : 


\title{
Application of the Direct Colony TLC Method for Identification of Phytopathogenic Bacteria
}

\author{
Nobuaki Matsuyama, Ismail Hossain Mian*, Abdul Mannan Akanda* \\ and Naruto Furuya
}

Laboratory of Plant Pathology, Faculty of Agriculture, Kyushu University 46-01, Fukuoka 812, Japan.

(Received November 27, 1992)

\begin{abstract}
Direct colony thin-layer chromatography was applied for the identification of the phytopathogenic bacteria. This method involves two steps such as the extraction of lipids from bacterial cells and their development. Chloroform-methanol (2:1, v/v) and chloroform-methanol-5M ammonia $(60: 25: 4, \mathrm{v} / \mathrm{v})$ were used as the solvents for the first and second developments, respectively. Omission of the first step and the direct development with the second solvent gave worse results with tailing. Inter-genus differences, at least, were observed among the chromatograms. Striking difference of chromatogram was observed between Clavibacter spp. (Gram positive) and others (Gram negative). The chromatograms of Erwinia spp. were characteristic and quite different from those of Xanthomonas spp. and Agrobacterium tumefaciens. Although some difficulties like the cases of Pseudomonas spp. are still remaining, the practical usefulness of this method for a rapid identification of phytopathogenic bacteria was certainly verified.
\end{abstract}

\section{INTRODUCTION}

The identification of phytopathogenic bacteria has been conducted by physiological, pathological and serological tests. While, the analytical data on bacterial cell membrane have been used for the identification and classification of the bacteria. Especially, the usefulness of the membrane lipid analysis has been emphasized (Ikemoto et al., 1978, Suzuki and Komagata, 1983, De Boer and Sasser, 1986, Chase et al. 1992, Kori et al., 1992). However, these methods take time for the preparation of the samples and are not convenient in the case of identification of many isolates.

A rapid and easy identification method by silica-gel thin layer chromatography (TLC) was invented by Matsuyama, T. et al. (1987) for the identification of Serratia spp. This direct colony TLC method involves two steps such as the extraction of lipids from the bacterial cells and the development of the extracts on a same TLC plate. Application of this method for the rapid identification of phytopathogenic bacteria was conducted. The abstract has been presented elsewhere (Matsuyama et al., 1992) and the details will be contributed in this report.

\footnotetext{
* Department of Plant Pathology, Institute of Post-graduate Studies in Agriculture (IPSA), Salna, Gazipur, Bangladesh.
} 


\section{MATERIALS AND METHODS}

Bacteria: The various phytopathogenic bacteria of different sources were used for this experiment (Table 1).

Culture: The culture of the bacteria was conducted at $25^{\circ} \mathrm{C}$ for $3,5,15$ days on the slant of the modified potato semi-synthetic agar medium (PSA): $39 \mathrm{~g}$ PDA medium (OXOID ${ }^{\mathrm{R}}$, UNIPATH Ltd.), 2.0 $\mathrm{g} \mathrm{Na}_{2} \mathrm{HPO}_{4} \cdot 12 \mathrm{H}_{2} \mathrm{O}, 0.5 \mathrm{~g} \mathrm{Ca}\left(\mathrm{NO}_{3}\right)_{2} \cdot 4 \mathrm{H}_{2} \mathrm{O}, 5 \mathrm{~g}$ peptone, 11 distilled water, $\mathrm{pH}$ 7.0. In this medium, sucrose was substituted with glucose and this part was different from the original PSA medium.

Thin layer chromatography: One loopful bacterial cells was taken from the colony of each isolate and spotted on silica gel TLC plate ( $\mathrm{Si} 60,0.25 \mathrm{~mm}$, Merck Co.), directly. Spots were separated $1.5 \mathrm{~cm}$ each other and aparted $1.0 \mathrm{~cm}$ from the bottom of the edge of TLC plate. The plate was developed at first with chloroform-methanol (CM, 2:1, $\mathrm{v} / \mathrm{v}$ ) for ca. $10 \mathrm{~min}$ until the solvent front will reach $6 \mathrm{~cm}$-line from the origin. The plate was dried completely at room temperature, scraped off the bacterial cells and developed with the second solvent, chloroform-methanol-5M ammonia (CMA, 60:25:4, $\mathrm{v} / \mathrm{v})$ for ca. 1 hour.

After development, the plate was dried well, sprayed with ninhydrin solution

Table 1. List of phytopathogenic bacteria used in this experiment.

\begin{tabular}{lll}
\hline \multicolumn{1}{c}{ Phytopathogenic bacteria } & & Sources \\
\cline { 1 - 1 } Clavibacter michiganensis subsp. sepedonicum 1 & & NIAES \\
Clavibacter michiganensis subsp. sepedonicum 17-4 & NIAES \\
Clavibacter michiganensis subsp. michiganensis N6601 & & NIAES \\
Clavibacter michiganensis subsp. michiganensis N6204 & NIAES \\
Erwinia chysanthemi pv. chysanthemi Ku8601 L1 & AKU \\
Enwinia carotovora subsp. carotovora 489-4 & LSPPM \\
Ervinia carotovora subsp. carotovora EH8519 & NIAES \\
Xanthomonas campestris pv. citri N6102-1 & NIAES \\
Xanthomonas oyzae pv. o ryzae Q7463 & KNAES \\
Xanthomonas oryzae pv. oyzae T7174 SNR (12) & HNAES(TKAES) \\
Xanthomonas oyzae pv. oyzae Q7781 & KNAES \\
Agrobacterium tumefaciens 1-3a & AKU \\
Agrobacterium tumefaciens 1-SKRa & AKU \\
Pseudomonas glumae Kyu 82-34-2 & KNAES \\
Pseudomonas glumae 2 & KNAES \\
Pseudomonas solanacearum 8224 & NRSVOT \\
Pseudomonas solanacearum 8109 & NRSVOT \\
Pseudomonas solanacearum C319SR & KTES \\
Unidentified strain UI-PS6227 & AKU
\end{tabular}

NIAES: National Institute of Agro-Environmental Sciences, Ibaraki, Japan AKU : Faculty of Agriculture, Kyushu University, Fukuoka, Japan

HNAES: Hokuriku National Agricultural Experiment Station, Niigata, Japan

TKAES: Tokai-Kinki Agricultural Experiment Station, Japan

KNAES: Kyushu National Agricultural Experiment Station, Kumamoto, Japan

LSPPM: Laboratory of Seed and Post-Harvest Disease, Plant Pathology and Microbiology

Division, Department of Agriculture, Thailand

NRSVOT: National Research Station of Vegetable, Ornamental and Tea, Iwate, Japan

KTES : Kagoshima Tobacco Experimental Station, Kagoshima, Japan 
(Ninhydrin spray, Tokyo Kasei Co.) and kept at $100^{\circ} \mathrm{C}$ for $10 \mathrm{~min}$. After the recording of the chromatogram, 50\% sulfuric acid solution was sprayed and the plate was kept at $130-150^{\circ} \mathrm{C}$ for $15 \sim 30 \mathrm{~min}$.

The solvent, chloroform-methanol-water (CMW, 60:25:4, v/v) was also useful for the second development substituting for CMA solutions.

\section{RESULTS AND DISCUSSION}

In the case of the identification and a systematic classification of phytopathogenic bacteria, numerous tests on the structures and functions of bacteria have been required. These tests are quite time-consuming and need lots of facilities. Therefore more rapid and easy ways have been requested.

In 1987, Matsuyama et al. firstly reported the direct colony TLC method which is quite unique and practically useful.

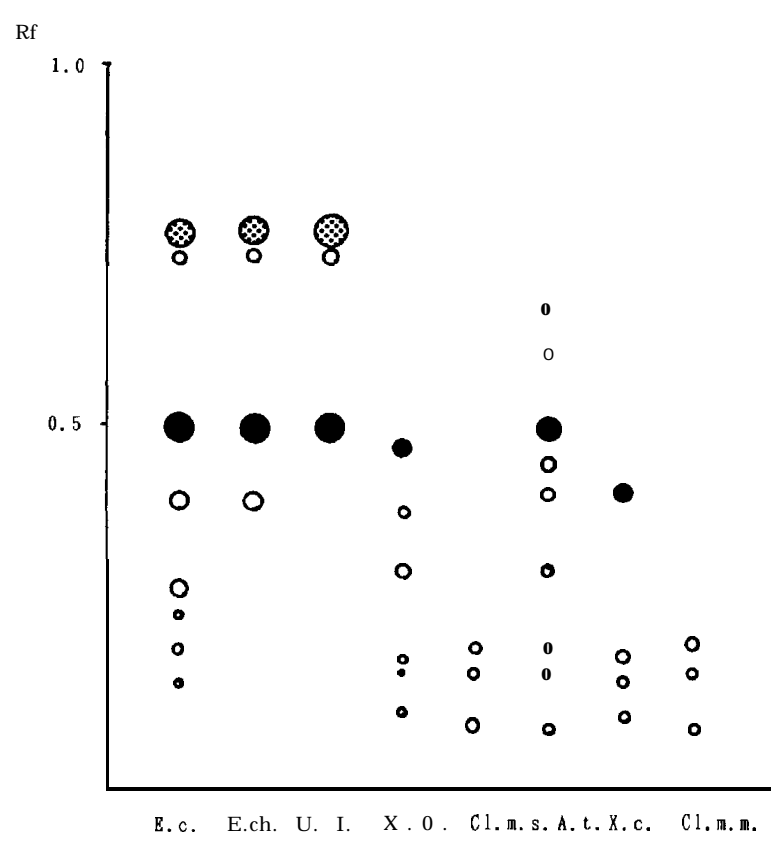

Fig. 1. Diagrammatic representation of the results obtained by the direct colony thinlayer chromatography.

E. c.:Erwinia carotovora subsp. carotovora 489-4

E. ch.: Erwinia chrysanthemi pv. chrysanthemi Ku8601 L1

U. I.: Unidentified strain UI-PS6227

X. o.: Xanthomonas oryzae pv. oryzae Q7463

Cl. m. s.: Clavibacter michiganensis subsp. sepedonicum 1
A. t.: Agrobacterium tumefaciens 1-3a
X. c.: Xanthomonas campestris pv. citri N6102-1
Cl. m. m.: Clavibacter michiganensis subsp. michiganensis N6601 
As shown in Fig. 1, the chromatogram of each bacterium is characteristic. Striking difference was observed between Gram positive bacteria, Clavibacter michiganensis subspecies, and Gram negative bacteria. This result, however, was expected because of the distinct diversity between Gram positive and negative bacteria in various characteristics. Among Gram negative bacteria, the chromatograms of Erwinia spp. were distinct from others. The spots of Rf 0.79 and 0.75 were characteristic to the Erwinia spp. and the spot at ca. Rf 0.5 was larger and clearly different from that of Xanthomonas spp. The chromatogram of the unidentified isolate (Fig. 1, 3rd lane from the left) showed the characteristics of Erwinia spp. The electron microscopic observation also supported the identification by this TLC method.

Characteristic spot at Rf 0.78 was not easily detectable when CMW solvent was used for CMA. Ammonia in the solvent could relate with this result. The properties of the substances which are detectable with ninhydrin are unknown now. The possibility of aminolipids which have been stressed recently as the benchmarks for distinction of bacteria will be clarified in future.

Well reappearance of the results was obtained if the conditions of the experiment were kept uniformly. The chromatograms of the bacteria cultured for 3-15 days were almost same and no distinct differences were observed. Omission of the first step with CM solvent and direct development with CMA gave worse results with tailing.

The chromatography of some isolates of Pseudomonas spp. gave sometimes worse results and the spots were irregular-shaped. These trends seemed to be fixed character for some Pseudomonas isolates. Some extra-cellular substances could disturb the smooth extraction of lipids with the CM solvent. However, these problems were sometimes solved by using King B medium for PSA medium.

In this experiment, inter-genus distinction, at least, was succeeded and the interspecies or inter-pathovars distinction will be tried in near future by using many isolates of various origins. Although this direct colony TLC method could not be always applicable to the identification of Pseudomonas spp., this method will be useful mean for a rapid identification of phytopathogenic bacteria.

\section{ACKNOWLEDGEMENTS}

The authors are indebted to Prof. Dr. M. Sugiura of Kyushu University (The team leader of IPSA project, in Bangladesh) for his encouragement.

\section{REFERENCES}

Chase, A. R., R. E. Stall, N. C. Hodge and J. B. Jones 1992 Characterization of Xanthomonas campestris strains from aroids using physiological, pathological, and fatty. acid analyses. Phytopathology, 82: 754-759

De Boer, S. H. and H. Sasser 1986 Differentiation of Erwinia carotovora ssp. carotovora and $E$. carotovora ssp. atroseptica on the basis of cellular fatty acid composition. Can. J.Microbiol., 32: 796-800

Ikemoto, S., H. Kuraishi, K. Komagata, R. Azuma, T. Suto and H. Muraoka 1978 Cellular fatty acid composition in Pseudomonas species. J.Gen.Appl.Microbiol., 24: 199-213

Kori, Y., N. Furuya, K. Tsuno and N. Matsuyama 1992 Differentiation of Enviniachrysanthemi 
and $E$. carotovora by the cellular fatty acid analysis. J. Fac.Agr., Kyushu Univ., 37(2): 173-178

Matsuyama, N., Ismail Hossain Mian and Abdul Mannan Akanda 1992 Application of the direct colony TLC method for the identification of phytopathogenic bacteria, Proc. of Annual Meeting of Bangladesh Phytopath. Soc., in press.

Matsuyama, T., M. Sogawa and I. Yano 1987 Direct colony thin-layer chromatography and rapid characterization of Serratiamarcescens mutants defective in production of wetting agents. Applied and Environmental Microbiology, 53: 1186-1188

Suzuki, K. and K. Komagata 1983 Taxonomic significance of cellular fatty acid composition in some coryneform bacteria. Int. J. Syst. Bacteriol., 33: 188-200 